ISSN 2415-8712 (on-line); ISSN 1682-671X (print)

Shodoznavstvo, 2021, No. 88, pp. 133-156

doi: https://doi.org/10.15407/skhodoznavstvo2021.88.133

UDC 94:323.1(=512)(477.62)

\title{
TURKIC-SPEAKING POPULATION OF THE DONBAS IN THE SOVIET INDIGENIZATION POLICY
}

\section{Martynchuk}

$\mathrm{PhD}$ (History), Associate Professor of the Department of History of Ukraine and Special Branches of History

Vasyl' Stus Donetsk National University

2, Hrushevskyi Str., Vinnytsia, 21050, Ukraine

vikusha.im@gmail.com

ORCID: 0000-0002-9665-3289

\section{O. Otzemko}

$\mathrm{PhD}$ (History), Associate Professor of the Department of History of Ukraine and Special Branches of History Vasyl' Stus Donetsk National University 2, Hrushevskyi Str., Vinnytsia, 21050, Ukraine otzemko@gmail.com

ORCID: 0000-0002-3164-1148

The article studies aspects of the Soviet indigenization policy of the 1920 s - early 1930s regarding the Turkic-speaking population of the Donbas region, namely its two groups - Tatars and Urums (Turkophone Greeks). The Donbas was formed as one of polyethnic regions of Ukraine covering the territory of modern Donetsk and Luhansk regions. The research is based on a wide range of sources, primarily documents of the Communist Party (as it fully controlled the implementation of indigenization), record keeping of authority bodies, statistical and reference materials. We have analyzed indigenization measures aimed at the Tatars living in the region and a large ethnic Turkic-speaking community of Greeks from the Azov region (Urums).

2021 I. Martynchuk and O. Otzemko; Published by the A. Yu. Krymskyi Institute of Oriental Studies, NAS of Ukraine on behalf of The Oriental Studies. This is an Open Access article distributed under the terms of the Creative Commons Attribution License (https://creativecommons.org/licenses/by-nc/4.0/). 
The principal focus is on the issues of administrative-territorial zoning and the attempts to solve the language problem of the Turkic-speaking population in the Donbas. We have also touched upon ideological and organizational principles of indigenization. The discussion deals with three national Greek districts created in 1926-1931, for instance Mangushsky district with Urums population and 14 Urums village councils. However significant shortcomings in their activities led to low voter turnout of the local population. The article concludes that the language issue became crucial for Tatar and Urum population of the Donbas due to the need to create an administrative apparatus on the national grounds and conduct office work in national languages. The solution of the language problem was also of political importance: the governing bodies wanted to make favorable conditions for the spread of the Soviet way of life, anti-religious propaganda and promotion of the "international education" of the Turkic-speaking population. Generally speaking, the problems of the Turkic population of the Donbas were not solved with indigenization. At the same time, it contributed to their involvement in the accelerated processes of Soviet modernization of the Donbas which became more severe and repressive in the early 1930s.

Keywords: Turkic-speaking population, Tatars, Urums, indigenization, administrative-territorial zoning, the Donbas

\section{Introduction}

Ethnic issues have always been extremely important for Ukraine. At various times, they were either ignored by governments or became part of their domestic political agenda. Regardless of this, interethnic relations remained an integral part of the political, economic and cultural life of the country's population and they directly affected both the daily life of the inhabitants of different regions and the situation inside and around Ukraine. Interethnic relations have their peculiarities in the history of the Donbas in the East of the country which was formed as one of Ukraine's polyethnic regions and became a place for testing various, not always successful, practices regarding national communities among which the Turkic-speaking population stood out prominently.

The aim of the article is to study the directions of the Soviet indigenization policy (localization policy is another synonym used in historic literature) in the 1920 s - early 1930 s in relation to the Turkicspeaking population of the Donbas that includes Tatars and Urums 
(Turkophone Greeks) who settled in the region under various circumstances. Measures of Urum indigenization will be considered in connection with the general policy towards the Greek community of the Donbas that was made of Turkophone Greeks (Urums) and Hellenophone Greeks (Romeiis). The main focus is on the issues of administrative-territorial zoning and the attempt to solve the language problem of the Turkic-speaking population of the region which is directly related to it.

The geographical framework of the study includes the territory of modern Donetsk and Luhansk regions which underwent significant transformations during the specified period due to the three-stage administrative-territorial reform.

The study is based on the following sources: documents of central and local bodies of the Communist Party as in the 1920s it already completely controlled all aspects of life in Soviet Ukraine, in particular the implementation of the indigenization policy; record keeping of government bodies (protocols, circulars, accounts, reports); statistical and reference materials. These sources are presented in publications of current events [Novi administratyvni... 1930] as well as in scientific archaeographic collections. The unpublished part of the examined sources is stored in the funds of the Central State Archives of Supreme Bodies of Power and Government of Ukraine (TsDAVO of Ukraine) and the State Archive of Donetsk Region (DADO).

Indigenization issues in the USSR, including the Turkic-speaking population, were studied by researchers of different times: D. Spiridonov, V. Navshirvanov, S. Yali in the Soviet period [Navshirvanov 1924; Spiridonov 1930; Yali 1931]; most active modern scientists L. Yakubova, O. Rubl'ov, P. Dem'yanchuk [Yakubova 2014; Rubl'ov 2014; Dem'yanchuk 2017]. Some aspects were considered in a general work devoted to the Donbas by the Japanese scholar Hiroaki Kuromiya [Kuromiya 2002]. We must also mention the works by the well-known Ukrainian orientalist Ahatanhel Kryms'kyy and the collection dedicated to the Urums of the Azov region edited by Oleksandr Harkavets' [Kryms'kyy 1974; Harkavets' 1999].

Methods of analysis and synthesis, systemic, statistical and historical-comparative methods were used to reach the aim of the research. 


\section{Ideology and Organization of the Indigenization Policy}

The Bolsheviks were forced to introduce temporary changes in national policy after the formation of the USSR. In April 1923 the Twelfth Congress of the Soviet Union Communist Party of Bolsheviks (CPSU (B)) announced its course to eliminate economic and cultural inequality between peoples and defined the principles of the "indigenization" policy. Modern researchers view it as a contradictory process and connect it not only with the forced concessions to the national elites of the allied "suburbs" that proved themselves during the revolutionary transformations in the territory of the former Russian Empire. Indigenization is interpreted as an important component of Soviet modernization of society which included a range of socio-economic, socio-political and cultural transformations, a radical restructuring of society based on new principles [Rubl'ov 2014, 49, 104]. A significant part in the implementation of this policy was played by the Donbas which was a polyethnic region and due to the compact location of ethnic groups became one of the venues for a huge political experiment that took place under the slogan of providing ethnic communities with opportunities for national and cultural development. One direction of this "experiment" included the implementation of administrative-territorial reform on the national principle.

This gives grounds for some researchers to assume that the Donbas was considered by the Bolshevik party leadership as a prototype of a future ethnocultural project that was later implemented in the concept of "a new community, i.e. the Soviet people" [Yakubova 2014, 60].

Despite the adoption of the Decree of the All-Ukrainian Central Executive Committee and the Council of People's Commissars of the USSR "On Measures to Ensure Equality of Languages and on Assisting the Ukrainian Language Development" on August 1, 1923, the main provisions of the national policy, namely the proclamation of equality of languages, creating national administrative territories were mostly declarative in nature during the initial stage. The first step of administrative-territorial zoning (1923), which was carried out together with the indigenization policy, did not take into account the requirements of the promised national-territorial administrative reform, so the second stage of zoning took into account the national factor. 
The legal basis for the formation of national administrative-territorial units was laid by the Decree of the Council of People's Commissars of the USSR "On the Allocation of National Districts and Village Councils" of August 29, 1924 and the IV session of the AllUkrainian Central Executive Committee on February 19, 1925. The latter act established that a national district may be formed if there were at least 10 thousand people of a certain nationality on its territory, and a national village council required 500 people [Protokoly No. 7-31..., ark. 4]. It should be noted that a regular district in Ukraine was formed with minimum 25 thousand people dwelling on its territory, and the village council needed 1 thousand people.

All work on the study of the national composition of the population and the allocation of national administrative-territorial units was carried out by the Central Administrative-Territorial Commission (CATC) at the All-Ukrainian Central Executive Committee and its local branches with the participation of specialists from other state institutions. CATC departments at the Donetsk local executive committee and district committees were established in 1924. First, local departments worked to determine the possibility of national zoning, studied compact groups of national minorities, their number; inquired about the mood of the population regarding zoning.

The intensification of the indigenization process was associated with the start of the Central Commission for National Minorities of Ukraine (CCNM) at the All-Ukrainian Central Executive Committee in April 1924. It accumulated all directions of the reform implementation [Novi administratyvni... 1930, 266]. The commission took over the functions of the Department of National Minorities that worked under the People's Commissariat for Internal Affairs (NKVD), it inherited the structure expanding and specifying areas of work and was to satisfy and protect the rights of ethnic groups in the USSR. But the main purpose of the body was to involve national communities in the process of Soviet construction as soon as possible. On March 27, 1924 three national sections began operating in Donetsk province: Jewish, German and Tatar. The established local authorities began their work on identifying settlements of national minorities in the region, preparing for the implementation of indigenization measures. 
According to Table 1, the Donbas belonged to the polyethnic regions of Ukraine; it was characterized by diversity and dynamism of the ethnic composition of the population that varied in characteristics in different districts, changed rapidly under the influence of various factors, the main of which was fast industrial development.

Table 1

\section{Dynamics of the National Composition of the Population of the Donbas according to the Censuses of 1923 and 1926}

[Based on: Itogi sploshnoy podvornoy... 1923;

Vsesoyuznaya perepis' naseleniya 1926 g... 1929, $16-18,33-35,340-353]$

\begin{tabular}{|l|l|c|c|c|c|}
\hline № & \multicolumn{1}{|c|}{ Ethnos } & 1923 & $\%$ & 1926 & $\%$ \\
\hline 1. & Ukrainians & 1609723 & 63,93 & 1879002 & 64,20 \\
\hline 2. & Russians & 655962 & 26,05 & 764724 & 26,12 \\
\hline 3. & Germans & 56834 & 2,26 & 65010 & 2,22 \\
\hline 4. & Greeks & $\mathbf{8 6 6 1 5}$ & $\mathbf{3 , 4 4}$ & $\mathbf{9 8 2 7 7}$ & $\mathbf{3 , 3 6}$ \\
\hline 5. & Jews & 42727 & 1,70 & 54453 & 1,86 \\
\hline 6. & Tatars & $\mathbf{5 3 4 7}$ & $\mathbf{0 , 2 1}$ & $\mathbf{1 4 6 4 8}$ & $\mathbf{0 , 5 0}$ \\
\hline 7. & Bulgarians & 867 & 0,03 & 1543 & 0,05 \\
\hline 8. & Poles & 6622 & 0,26 & 10099 & 0,35 \\
\hline 9. & Moldovans & - & - & 8688 & 0,30 \\
\hline 10. & Armenians & - & - & 2662 & 0,09 \\
\hline 11. & Belarusians & - & - & 15152 & 0,52 \\
\hline 12. & Others & 53313 & 2,12 & 12877 & 0,44 \\
\hline & Total: & 2518010 & 100 & 2927135 & 100 \\
\hline
\end{tabular}

\section{The Indigenization Policy of the Tatar Ethnic Community}

The territorial spread of ethnic minorities in the region was the result of political and economic processes that significantly influenced its development. The history of the Tatar population in the Donbas has a long tradition. Our study concerns the Volga Tatars (Muslim 
community in contrast to the Orthodox Urums) who seasonally worked in the coal mines of the Donbas from the second half of the $19^{\text {th }}$ century and even organized their local communities [Kuromiya 2002, 71]. According to Table 1 the number of Tatars in the region increased almost threefold from 1923 to 1926 from 5,347 to 14,648 and according to 1926 census they constituted $0.5 \%$ of the population. It reflected the general tendency of the growing rate of workforce to which they belonged. The majority (77.6\%) of the Tatar population of the region lived in such industrial districts as Artemivsk, Stalin and Luhansk mainly in cities (11230 out of 14648). Tatars together with Jews, Poles and Russians were the most urbanized ethnic community in the Donbas [Vsesoyuznaya perepis' naseleniya...1928, 122-123; Dem'yanchuk 2017, 153]. In the second half of the 1920s - early 1930s the number of Tatar workers was replenished through recruitment, in particular in 1931 recruitees from the Tatar ASSR made 1/6 of 67 thousand newcomers to the mines of the region [Istoriya rabochikh... 1981, 247].

It should be noted that the national work had its own peculiarities among the Volga Tatars. The Tatar section of the provincial department of education dealt with this issue, after the administrative and territorial reform of 1925 it became the responsibility of district inspectorates of national minorities. The head of the Central Bureau of the Peoples of the East, the well-known statesman S. Galiev also took personal care of the issue. Only thanks to his practical help the Tatar section was finally able to start solving the most urgent tasks of their ethnic development [Protokoly No. 81, 82..., ark. 57]. The priority issues addressed by the Tatar section included the study of the possibility of national zoning of the Tatar population and the solution of the language issue.

In the first half of the 1920s the board of the CCNM considered the formation of Tatar national councils. But due to the dispersion of the population, temporary nature of their work (mostly mine workers), the formation of Tatar councils was deemed inexpedient, so it was decided not to engage them into the process of national zoning in the Donbas.

In 1926, the CCNM commission carefully surveyed the Tatar population in Artemivsk, Luhansk, and Stalin districts. After the 
commission chairman S. Aizatulin's presentation the members of the CCNM came to the conclusion that the problems of the Turkicspeaking peoples of Ukraine should be solved based on the experience and assistance of specialists and general public representatives of the Tatar Autonomous Republic [Protokoly No. 81, 82..., ark. 88]. Special attention was paid to the publication of educational literature and thematic periodicals in the Turko-Tatar language. For instance, books were supplied by the state publishing house of the Crimean ASSR, educational literature for the Tatar population was published by the State Publishing House of Ukraine, and since 1926 it was the business of the All-Ukrainian branch of the Central Publishing House of USSR Peoples. Turkic-language magazines "Eshche" ("Worker"), "Igencheliar" ("Students"), "Fen En Din" ("Religion"), "Marif Eshchese" ("Researcher"), "Uktiabr Balasi" ("October Kid"), "Udarnyklar" ("Drummers") were primarily aimed at a specific target audience such as workers and students, they dealt exclusively with the task to cover socio-political life of the republic campaigning for a new "Soviet" way of life and anti-religious propaganda [Lystuvannia z Narkomfinom..., ark. 13].

The language issue was another important task concerning the Tatar population of the Donbas (as part of the general Turkic-speaking community of the USSR). To be exact, it was the need to switch to the Latin alphabet. In the second half of the 1920s, there was a lively discussion of this subject among USSR specialists - historians, philologists, ethnographers. Scientific journals, party and Soviet journals published different views and discussions of the matter. The well-known Ukrainian orientalist A. Kryms'kyy also joined the discussion criticizing the first versions of the Latin alphabet [Kryms'kyy 1974, 568].

The main priorities of the transition to the Latin alphabet were as follows: it was easier to learn compared to the Arabic language that "had too many dots, required enhanced printing production and the language in general in its pure form did not meet the needs of the population". As a result of the discussion it was decided to retain the positive aspects of the Arabic language as it was closer to the peoples from the East and at the same time introduce the Latin alphabet [Spiridonov 1930, 171-181; Tyuryakulov 1924, 38-40; Navshirvanov 
1924, 41-44]. Only since 1928 they started talking about the transition of the teaching process in Tatar schools to the Latin alphabet. This issue was postponed until the language reform in the Crimean Autonomous Soviet Socialist Republic. Thus, the process of introducing the Latin alphabet stretched over time and began only in 1929.

The introduction of the new alphabet was primarily of political significance. Its introduction in Soviet cultural, educational, and other institutions was to become a platform for spreading the propaganda of the "Soviet way of life" and anti-religious propaganda, to promote the acceleration of class differentiation and international education of workers of Turko-Tatar origin, to involve them in Soviet construction.

Solving the language issue of the Donbas Tatar population had problems that were generally characteristic of the work with national minorities in the region. Local officials reported an increase in school enrollment of national minorities, the CCNM concluded that in the 1927/28 academic year there were 9 Tatar (33 groups, 337 students) schools in the Stalin district, and 3 Tatar schools for 90 students in the Artemivsk district [Vidomosti, tablytsi, spysky..., ark. 10]. At the same time, the People's Commissariat of Education of the USSR stated that all the Donbas districts lacked educational facilities, qualified teachers, sufficient educational materials and literature in the national minorities languages. As a result, Tatar youth were forced to study in Russian and Ukrainian schools. But not all Tatars spoke Russian or Ukrainian so not all of them attended schools. It was impossible to establish the exact number of children not covered by the secondary education due to the mobility of the Tatar population. Thus, we can only talk about a formal increase in the number of educational institutions and groups while appropriate conditions for studying were absent. However, despite the low quality of education, Tatar young people were actively taught the basics of the communist worldview [Dem'yanchuk 2017, 157]. In addition, in the late 1930s, in the process of the final curtailment of indigenization, the Latin alphabet was replaced by the Cyrillic alphabet which also contributed to the Russification of the Turko-Tatar community.

In general, the problems of the Donbas Tatar population were not solved during the indigenization. Tatars mostly worked in the mines, 
most of them were unskilled workers, some of them were illiterate, the life and living conditions were extremely difficult which was typical of the region's mining villages in the 1920s.

\section{Indigenization of the Urums}

The Urums were part of the Greek population that settled in the Azov region as a result of resettlement from the Crimea in the late $18^{\text {th }}$ century. The presence of a Turkic-speaking group among 18.5 thousand displaced Greeks was conditioned by the peculiarities of their centuries-old settlement in the Crimea alongside the Tatars [Etnichni menshyny... 1996, 35].

The Greeks lived in a fairly isolated community the internal balance of which was shaken by the reforms in the 1860s and later by the events of 1914-1921. Nevertheless, the Greek ethnic community remained traditionally closed, stable in terms of territory and number, so despite the overall increase between 1923 and 1926, the percentage of Greeks in the region's population remained almost unchanged at $3.44 \%$ and $3.36 \%$ respectively (Table 1 ). The Urums constituted about half of the region's 98,000 Greeks which according to 1926 census were concentrated in Mariupol (64.2 thousand) and Stalin districts (33.5 thousand). The main occupation of the Greeks, including the Urums was agriculture [Vsesoyuznaya perepis' naseleniya... 1928, 118-119, 123; Yakubova 2010, 182, 207].

It is worth mentioning that the problems of national zoning of Urums and Romeiis emerged from the very beginning of indigenization. The Urums used the Crimean Tatar language in everyday life supplementing it with words and expressions of Greek origin. The Ukrainian orientalist A. Kryms'kyy noted in 1930 that the Urums "still used the Crimean language that they spoke in the 18th century in the cities of the southern Crimea. They brought some of their literature with them written in Turkic, not in Arabic but in Greek letters adapted to the Turkic sounds" [Kryms'kyy 1974, 506]. The researcher hoped that the efforts of the People's Commissariat of Education of the USSR that took them under its care "as one of the national minorities in Ukraine" would publish educational books and grammar essays in their vernacular [Kryms'kyy 1974, 507]. But at the beginning of the indigenization process these important details were not taken into account. 
Thus, the problem of creating national administrative-territorial units (districts, village councils) was directly related to the language issue which became urgent not only because of the needs of national education and culture but also due to the creation of administrative apparatus on the national basis, the introduction of office work in national languages. Mariupol Region administrative-territorial committee (ATC) considered it impractical to create Greek administrativeterritorial units pointing to the differences in the dialects of people residing even in nearby villages. According to the correspondence, district ATCs considered ethnic separation artificial, national identity non-existent and sought the opportunity to change all office work into Russian [Dopovid' referenta..., ark. 13]. But the majority of the Greek population of the region enthusiastically accepted the idea of creating national administrative-territorial units, some peasants considered the reform to be a return to benefits granted to the Greeks in the late 18th century that were abolished during the reforms of the $1860 \mathrm{~s}$ and $1870 \mathrm{~s}$.

In the summer of 1925, a scientific ethnographic expedition was organized to settle the administrative and linguistic issue with the aim of close examining all the linguistic dialects used by the Urums and Romeiis of the Azov region. The commission was supposed to make a thorough report at a meeting of the Presidium of the All-Ukrainian Central Executive Committee. The secretary of the Greek bureau $\mathrm{S}$. Yali was appointed chairman of the commission on behalf of the CCNM [Vytyahy z protokoliv zasidan' Maloyi..., ark. 21]. In the autumn of 1925 the report of the commission was presented and discussed. After a detailed study of the language issue carried out by members of the ethnographic commission, staff of the Institute of Oriental Studies, a special commission of the CCNM headed by $\mathrm{S}$. Yali, it was concluded that national village councils and districts should be immediately created separately for "Greek Tatars" (Urums) and "Greek Hellenes" (Romeiis).

The 1925 expedition was not the last to detect serious problems of language reform and national-territorial zoning of the Azov Greeks. The Commission on the Study of Oriental Peoples Living in Ukraine organized by the All-Ukrainian Scientific Association of Oriental Studies (VUNAS) joined the study of the everyday culture of the 
Urums and Romeiis of the Azov region and the preparation of the language reform. On November 16, 1927, the CCNM adopted Resolution 3/13, according to which S. Yali, a member of the Cabinet for the Study of National Minorities, a member of the CCNM Presidium, was instructed to develop a special study program for Mariupol Greeks and unite its implementation with other research institutions [Potokoly 1-23..., ark. 77]. The scientific expedition that worked in July-August 1928 was to study the language dialects of the Greek population of the Azov Sea and their local diversity. The expedition included full members of VUNAS such as Professors I. Sokolov, M. Derzhavin, D. Spiridonov. The majority of respondents were students of Greek descent from the Mariupol district, Greek teachers and residents of villages in the Mariupol and Stalin districts with a predominantly Greek population. The conclusions of the commission stated the existence of many dialects which developed separately and in fact represented dialectal differences in each village [Lystuvannia z Narkomfinom..., ark. 11, 96]. The collected material was later studied and summarized by a specially formed CCNM commission which noted not only its exceptional scientific significance but above all its practical value.

However, the expeditions for studying the Azov Greeks paid more attention to the Romeiis ignoring the language problems of the Urums [Ponomariova 2007, 88].

The publication of literature in the national languages for the Romeiis and the Urums was to help solve the problem of indigenization for which purpose a Greek national publishing house was opened in Mariupol in 1930. At the end of 1933, the Donetsk Regional Greek Publishing House was established and the printing base of the Mariupol printing house was transferred there. Undoubtedly, periodicals in national languages were perceived as tools of national and cultural construction, searching for new forms and means of propaganda work, especially among children groups and youth [Martynchuk 2017, 172].

At the beginning of 1925/26 academic year 7 Urum and 8 Romeii schools were opened. In 1927/28 academic year there were already 17 Urum schools (83 groups, 2,987 students) and 27 Romeii schools in the Stalin District [Vidomosti, tablytsi, spysky..., ark. 10]. In 
1928/29 academic year there were 65 schools in the Mariupol and Stalin districts 35 of which were Urum and 30 Romeii ones [Dokumenty pro kultosvitniu robotu..., ark. 43].

However, during the implementation of teaching in national languages, the complexity of the Urum language problem became evident which was not taken into account before. The Urum language was the language of intergroup communication of the Mariupol Greeks until the end of the $19^{\text {th }}$ century giving way to Russian after the abolition of the Greek district autonomy. However, according to studies even in the 1920s the Hellenophone Greeks understood and could communicate in the Urum language while the Turkopnones did not speak Rumeika. The Urum writing is still a debatable issue although in the XIX - early XX century there were some cases of writing in Greek letters in the Urum language or using the Russian alphabet for everyday writing and correspondence, some manuscripts have been preserved in the Urum language [Ponomariova 2007, 87; Yakubova 2010, 205-206].

During indigenization ethnic communities received a legislative basis for the revival of the national language, creation of their own alphabet as the reform was aimed at taking into account local dialects. However, the "transformation" of the Urum language was uncontrollable. Attempts to settle the Urum language issue were based on the results of the above-mentioned commission active in 1925, which did not have qualified specialists and concluded that the Urum and Crimean Tatar languages were 90 percent similar. The outcome was the introduction of the Crimean Tatar language in Urum schools. In fact the languages were not identical which complicated the transition to the Latin alphabet [Ponomariova 2007, 89; Harkavets 1999, 6].

Besides, the language reform was opposed by some Greeks themselves who believed that the Greek language was used only in the countryside (a folk, "peasants" language). It was better to learn Russian (the "cultural" language) to communicate with the "outside world" and receive education. This opinion was also characteristic of other ethnic communities of the USSR which ultimately corresponded to the "abridged version of the Bolshevik language modernization" [Yakubova 2010, 207-208]. This attitude was also caused by the above-mentioned mechanical introduction of the Crimean Tatar 
language in schools of Urum settlements, which brought about dissatisfaction of the local population. The cessation of indigenization in the early 1930 s, the intensification of repressions in the country nullified the work that had been just begun.

The work of CCNM in 1926-1931 resulted in the establishment of 14 Urum and 16 Romeii village councils, 3 national Greek territories: Mangush district (predominantly Urums) and Sartan district (predominantly Romeiis) on the territory of Mariupol region, Velyko-Yanysolsky district in Stalin region. According to the documents national zoning of these ethnic groups was more effective than that of other ethnic minorities primarily due to their compact settlement [Merezha natsional'nykh..., арк. 154].

During the period of indigenization $87.2 \%$ of Urums and Romeiis of Ukraine were covered by the national zoning, the percentage for the rural population was even higher $-93.3 \%$. Mangush district stood out among the formed Greek districts having the highest density of ethnic minorities: the Urums accounted for $89 \%$ of the total population. At the same time Sartan and Velyko-Yanysolsky national districts had $57 \%$ and $58 \%$ Romeiis respectively [Vypysy z protokolu zasidannya TsATK..., ark. 38].

It should be said that the representation of national minorities in local authorities was disproportionate to the population which reflected the distribution of political forces in the central government. Ethnic Russians predominated as chairmen of district and regional executive committees, only in the lower Soviet management the number of representatives of other national communities more or less reflected the real composition of the population.

Mariupol region had most ethnic representatives. The total number of members of village councils in 1927 was 3304 people of whom 1308 or $39.6 \%$ were representatives of ethnic minorities [Protokoly zasidan' TsK..., ark. 159]. Despite the fact that the Greek population, as mentioned above, accounted for $28.2 \%$ of the population of the region Greeks took $19 \%$ (628 people) of seats in village councils. At the same time we must say that there were 239 Greeks in Urum village councils (81 \%) [Statystychnyy byuleten'... 1926-1927, 1-9]. In general, national village councils and districts had the shortcomings characteristic of the Soviet governing system in general in the 1920s. 
They were, most notably, excessive control of party bodies over elections, threats, declaring people who did not agree with them to be party enemies, removing them from the lists of voters [Zvit Donets'koyi..., ark. 12].

All this provoked resistance from voters, their low participation and negatively affected the work of local authorities. During the inspection of Starokrymsky District Executive Committee in June 1923 a number of shortcomings were revealed, in particular red tape and closed nature of village councils, lack of contact with the "GreekTatar" population. It was stated that "only the chairman and the secretary were actually working". In November 1924 Donetsk province executive committee stated: "Mariupol region has very poor participation and weak leadership, only the visibility of work is maintained while broad peasant masses are not involved in work at all" [Rubl'ov 2014, 114]. The situation did not change in the early 1930s. For example, Staro-Karansky district had $66 \%$ of national minorities, in particular $36 \%$ of 36,540 people were Urums, but the district executive committee did not take any practical measures to implement the law on equality of languages. An inspection of the implementation of the law in Urum village councils (Staro-Karansky and Staro-Hnativsky) demonstrated that the records were kept exclusively in Russian without taking into account the ethnic factor. StaroKaransky District Executive Committee did not take measures to train relevant personnel to work with ethnic minorities. Meetings, proceedings, gatherings of national village councils were held mainly in Russian. The chairmen and secretaries of these village councils, although being able to speak "Greek-Tatar", were illiterate in the language. And this was a typical picture for the whole region [Dopovidna zapyska..., 195].

The distortions have resulted in low voter turnout among members of national minorities, including the Urums. At the First All-Ukrainian Conference on Work with National Minorities of Ukraine in 1927 it was noted that, contrary to expectations, the turnout remained low $-53.6 \%$. Most voters were not from Unwealthy Peasants Committees (organizations of Ukrainian poor peasants who participated in collectivization in 1920-33) and party cells but from wealthy villagers who focused the issues of price discrepancy, the Bolsheviks' 
economic policy in the countryside. That small percentage of members of national minorities who took part in the elections voted for wealthy peasants whom the Bolsheviks called "dead wood", "negative elements". These facts, according to researchers, indicate extremely low support of the interests of ethnic communities in national areas. It was merely a form of their accelerated Sovietization. The policy of indigenization in fact proved to be a proxy of Russification of national minorities in the region [Yakubova 2014, 54, 57].

The problem of the Azov Greeks indigenization (in particular the Urums) was convincingly outlined by one of their key leaders S. Yali: in 1927 he noted that the question of "the Greek-Tatar language" spoken by about $40 \%$ of Ukrainian Greeks still remained unresolved; in 1928 he mentioned "terrible Russification" by which he meant Russian-language schools that encompassed $80-90 \%$ of Greek children; in 1931 he reported on the impressive illiteracy of the Mangush and Sartan districts authorities in minority languages. Emphasizing the fictitiousness of indigenization in the Urum settlements of the Staro-Karansky district, S. Yali noted that only first three groups were transferred to the Urum language curriculum while the rest of the school remained Russian-speaking; the Old Karan Grain Technical School also remained Russian-speaking; teachers were totally illiterate in the minority native language so the process of school indigenization actually came to a standstill; there was no educational literature [Rubl'ov 2014, 281, 282, 293, 294; Dopovidna zapyska..., 196].

In 1929 collectivization began and it dramatically changed the lives of the Urums who were mostly richer than their Ukrainian and Russian neighbors. Further formation of the administrative system, in particular the third stage of administrative-territorial reform, led to changes in the operation of Greek including Urum national districts. The resolution of the All-Ukrainian Central Executive Committee of June 2, 1932 asserted the formation of Donetsk region; Sartan, Mangush (Urum) national Greek districts were disestablished and annexed to Mariupol City Council [Rubl'ov 2014, 207]. Velyko-Yanysolsky district existed until the second half of the 1930s gradually losing its purpose. In 1934 the national Staro-Karansky district was created on the basis of the administrative-territorial unit of the same 
Turkic-Speaking Population of the Donbas in the Soviet Indigenization...

name, but the general trend indicated a steady decline in national administrative-territorial units which were finally terminated in 1939.

\section{Conclusion}

Thus, the indigenization policy of the Donbas Turkic-speaking population reflected contradictions, positive features and shortcomings that were characteristic of the whole country. Although the indigenization policy was carried out from the top-down like many other "campaigns" and was often not fully understood by communities, it created opportunities for national minorities including Turkicspeaking peoples to join public and political life, changed their isolated way of life.

On the other hand, public and political life was inherently Soviet and controlled by the Bolshevik government which suppressed any attempts to go beyond the prescribed ideological guidelines. This was evident from the onset of the personnel policy of the national administrative-territorial reform: only communists and the poor could make it to the newly created national authorities while ethnic minorities could only get to the level of village councils. It caused low voter turnout and skeptic if not negative attitude towards the authorities.

Besides, indigenization did not take into account the complexity of the Urums' language problem and did not solve it.

The small number and dispersion of the Tatar population of the Donbas region, shocking methods of production reconstruction and industrialization which ignored the workers' domestic problems, shortcomings in the activity of local commissions on national minorities prevented full implementation of the indigenization policy for this ethnic group.

In general, indigenization of Turkic-speaking population did not solve the problems of these ethnic minorities, but at the same time it contributed to their involvement in the accelerated processes of Soviet modernization of the Donbas region which became more severe and repressive in the early 1930s.

The Bolsheviks used indigenization to strengthen their power in Ukraine. The creation of an administrative machine, mostly national in its membership, presupposed complete dependence on the Moscow center. The forced weakening of control over national and cultural 
processes under the "dictatorship of the proletariat" created favorable environment for gradual Sovietization of education, science, culture and upbringing of a "new man" of the Soviet type as well as helped to reveal national self-consciousness with the purpose of its further elimination.

\section{BIBLIOGRAPHY}

Виписи 3 протоколів засідань ЦАТК про встановлення сітки Рад на 1928/1929 рік. Статистичні таблиці адміністративно-територіального поділу УРСР станом на 15.VII.28 p. i 01.I.30 p. // Центральний державний архів вищих органів влади та управління України (ЦДАВО України). Ф. 1. Оп. 5. Спр. 1177.

Витяги з протоколів засідань Малої Президії ВУЦВК / ЦДАВО України. Ф. 413. Оп. 1. Спр. 3.

Відомості, таблиці, списки національних шкіл та культосвітніх установ по округах України // ЦДАВО України. Ф. 413. Оп. 1. Спр. 381.

Всесоюзная перепись населения 17 декабря 1926 г.: краткие сводки. Вып. 4: Народность и родной язык населения СССР. Москва, 1928.

Всесоюзная перепись населения 1926 г. Т. ХІІІ. УССР. Степной подрайон. Днепропетровский подрайон. Горнопромышленный подрайон. Москва, 1929.

Гаркавець О. Уруми Надазов'я: Історія, мова, казки, пісні, загадки, прислів'я. Писемні пам'ятки. Алма-Ата, 1999.

Дем'янчук П. Другий комуністичний штурм та його вплив на етнокультурне середовище міст Донбасу // Регіональна історія України. Збірник наукових статей. Вип. 11. Київ, 2017.

Документи про культосвітню роботу серед грецького населення (витяги 3 протоколів, тези доповідей, резолюції, плани) // ЦДАВО України. Ф. 413. Оп. 1. Спр. 382.

Доповідна записка про стан запровадження закону про рівноправність мов серед населення національних меншостей України. Греко-татарські сільські ради. 1932 // Національні процеси в Україні: історія і сучасність. Документи і матеріали: у 2 ч. Ч. 2. Київ, 1997.

Доповідь референта підвідділу місцевих фінансів Сталінського окрфінвідділу Мізко Д. А. про обслідування місцевих фінансів 
Turkic-Speaking Population of the Donbas in the Soviet Indigenization...

Старо-Бешівського району // Державний архів Донецької області (ДАДО). Ф. Р-2. ОП. 1. Спр. 225.

Етнічні меншини в Україні // Етнічний довідник: в 3-х ч. Ч. 2. Київ, 1996.

Звіт Донецької губернської виборчої комісії 1924 р. // ДАДО. Ф. Р-1527. Оп. 2. Спр. 28.

История рабочих Донбасса: в 2 т. Т. 1. Киев, 1981.

Итоги сплошной подворной переписи Донецкой губернии (янв.-февр. 1923 г.). Т. 4. Итоги демографической переписи Донбасса. Харьков, 1923.

Кримський А. Тюрки, їх мови і літератури // Кримський А. Твори в п'яти томах. Т. 4. Сходознавство. Київ, 1974.

Куромія Г. Свобода і терор у Донбасі: Українсько-російське прикордоння, 1870-1990-і роки. Київ, 2002.

Листування з Наркомфіном, окрвиконкомами, редакціями газет, Центрвидавом про видання літератури мовами національних меншостей та доповідна записка Центрвидаву до ЦК КП(б)У про видання книг на мовах нац. меншостей // ЦДАВО України. Ф. 413. Оп. 1. Спр. 376.

Мартинчук I. Етнокультурні процеси в Донбасі у 192030-ті pp. // Нові сторінки історії Донбасу: Зб. ст. Кн. 26. Вінниця, 2017.

Мережа національних адміністративно-територіальних одиниць Донбасу (на 01.01.1931) // ЦДАВО України. Ф. 1. Оп. 4. Спр. 1248.

Навиирванов $B$. Почему мы стремимся перейти к латинскому алфавиту // Жизнь национальностей. 1924. № 1.

Нові адміністративні райони УСРР. Статистичний довідник. Харків, 1930.

Пономарьова I. Історія та сучасне функціонування мови греків-тюркофонів Приазов’я // Схід. 2007. № 2 (80).

Протоколи № 7-31 засідань Президії Маріупольського окрвиконкому з 8-го червня 1926 р. // ДАДО. Ф. Р-1202. Оп. 1. Спр. 79.

Протоколи № 81, 82 засідань ЦК національних меншостей та матеріали до них // ЦДАВО України. Ф. 413. Оп. 1. Спр. 158.

Протоколи № 1-23 засідань ЦК національних меншостей // ЦДАВО України. Ф. 413. Оп. 1. Спр. 242. 
Протоколи засідань ЦК національних меншостей та матеріали до них // ЦДАВО України. Ф. 413. Оп. 1. Спр. 168.

Рубльов О., Якубова Л. Органи етнополітичного регулювання в контексті політики коренізації: український досвід. Київ, 2014.

Спірідонов Д. Історичний інтерес до говірок маріюпольських греків // Східний світ. 1930. № 12.

Статистичний бюлетень Маріупольщини. 1926-1927. № 9-11.

Тюрякулов Н. К вопросу о латинском алфавите среди тюрков СССР // Жизнь национальностей. 1924. № 1.

Якубова Л. Грецьке село в горнилі “більшовицької перековки" (20-ті pp. XX ст.) // Проблеми історії України: факти, судження, пошуки. 2010. № 19 (1).

Якубова Л. Етнонаціональна історія Донбасу: тенденції, суперечності, перспективи в світлі сучасного етапу українського націотворення. Київ, 2014.

Ялі С. Греки в УСРР. Харків, 1931.

\section{REFERENCES}

Vypysy z protokoliv zasidan' TsATK pro vstanovlennya sitky Rad na 1928/1929 rik. Statystychni tablytsi administratyvno-terytorial'noho podilu URSR stanom na 15.VII.28 r. i 01.I.30 r., Tsentral'nyy derzhavnyy arkhiv vyshchykh orhaniv vlady ta upravlinnya Ukrayiny (TsDAVO Ukrayiny), F. 1, Op. 5, Spr. 1177. (In Ukrainian).

Vytyahy z protokoliv zasidan' Maloyi Prezydiyi VUTsVK, TsDAVO Ukrayiny, F. 413, Op. 1, Spr. 3. (In Ukrainian).

Vidomosti, tablytsi, spysky natsional'nykh shkil ta kul'tosvitnikh ustanov po okruhakh Ukrayiny, TsDAVO Ukrayiny, F. 413, Op. 1, Spr. 381. (In Ukrainian).

Vsesoyuznaya perepis' naseleniya 17 dekabrya 1926 g.: kratkiye svodki (1928), Vol. 4: Narodnost' i rodnoy yazyk naseleniya SSSR, Tsentr. statist. upr. SSSR, Moscow. (In Russian).

Vsesoyuznaya perepis' naseleniya 1926 g. (1929), Vol. XIII: USSR. Stepnoy podrayon. Dnepropetrovskiy podrayon. Gornopromyshlennyy podrayon, Izdaniye TsSU Soyuza SSR, Moscow. (In Russian). 
Turkic-Speaking Population of the Donbas in the Soviet Indigenization...

Harkavets' O. (1999), Urumy Nadazov"ya: Istoriya, mova, kazky, pisni, zahadky, prysliv"ya. Pysemni pam"yatky, Ukrayins'kyy kul'turnyy tsentr, Alma-Ata. (In Ukrainian).

Dem"yanchuk P. (2017), "Druhyy komunistychnyy shturm ta yoho vplyv na etnokul'turne seredovyshche mist Donbasu", in Rehional'na istoriya Ukrayiny. Zbirnyk naukovykh statey, Vol. 11, pp. 151-63. (In Ukrainian).

Dokumenty pro kul'tosvitnyu robotu sered hrets'koho naselennya (vytyahy z protokoliv, tezy dopovidey, rezolyutsiyi, plany), Ts $D A V O$ Ukrayiny, F. 413, Op. 1, Spr. 382. (In Ukrainian).

"Dopovidna zapyska pro stan zaprovadzhennya zakonu pro rivnopravnist' mov sered naselennya natsional'nykh menshostey Ukrayiny. Hreko-tatars'ki sil's'ki rady. 1932', in Natsional 'ni protsesy v Ukrayini: istoriya i suchasnist'. Dokumenty i materialy (1997), Vols. 1-2; Vol. 2, Vyshcha shkola, Kyiv, pp. 192-200. (In Ukrainian).

Dopovid' referenta pidviddilu mistsevykh finansiv Stalins'koho okrfinviddilu Mizko D. A. pro obsliduvannya mistsevykh finansiv Staro-Beshivs'koho rayonu, Derzhavnyy arkhiv Donets 'koyi oblasti (DADO), F. R-2, Op. 1, Spr. 225. (In Ukrainian).

"Etnichni menshyny v Ukrayini" (1996), in Etnichnyy dovidnyk, Vols. 1-3; Vol. 2, Feniks, Kyiv. (In Ukrainian).

Zvit Donets'koyi huberns'koyi vyborchoyi komisiyi 1924 r., $D A D O$, F. R-1527, Op. 2, Spr. 28. (In Ukrainian).

Istoriya rabochikh Donbassa (1981), Vols. 1-2; Vol. 1, Naukova dumka, Kyiv. (In Russian).

Itogi sploshnoy podvornoy perepisi Donetskoy gubernii (yanv.fevr. 1923 g.) (1923), Vol. 4. Itogi demograficheskoy perepisi Donbassa, Voyenno-Redakts. Sov. UVO im. Frunze, Kharkiv. (In Russian).

Kryms'kyy A. (1974), "Tyurky, yikh movy i literatury", in Kryms'kyy A., Tvory v p'yaty tomakh, Vol. 4, Skhodoznavstvo, Naukova dumka, Kyiv, pp. 447-584. (In Ukrainian).

Kuromiya H. (2002), Svoboda i teror u Donbasi: Ukrayins'korosiys'ke prykordonnya, 1870-1990-i roky, Vyd-vo Solomiyi Pavlychko "Osnovy", Kyiv. (In Ukrainian).

Lystuvannya z Narkomfinom, okrvykonkomamy, redaktsiyamy hazet, Tsentrvydavom pro vydannya literatury movamy natsional'nykh menshostey ta dopovidna zapyska Tsentrvydavu do TsK KP(b)U 
pro vydannya knyh na movakh nats. menshostey, TsDAVO Ukrayiny, F. 413, Op. 1, Spr. 376. (In Ukrainian).

Martynchuk I. (2017), "Etnokul'turni protsesy v Donbasi u 192030-ti rr.", Novi storinky istoriyi Donbasu: Zb. st., Kn. 26, pp. 167-78. (In Ukrainian).

Merezha natsional'nykh administratyvno-terytorial'nykh odynyts' Donbasu (na 01.01.1931), TsDAVO Ukrayiny, F. 1, Op. 4, Spr. 1248. (In Ukrainian).

Navshirvanov V. (1924), "Pochemu my stremimsya pereyti k latinskomu alfavitu', Zhizn' natsional 'nostey, No. 1, pp. 41-4. (In Russian).

Novi administratyvni rayony USRR. Statystychnyy dovidnyk. (1930), Derzhvydav "Hospodarstvo Ukrayiny", Kharkiv. (In Ukrainian).

Ponomariova I. (2007), "Istoriya ta suchasne funktsionuvannya movy hrekiv-tyurkofoniv Pryazov'ya”, Skhid, No. 2 (80), pp. 86-91. (In Ukrainian).

Protokoly No. 7-31 zasidan' Prezydiyi Mariupol's'koho okrvykonkomu z 8-ho chervnya 1926 r., DADO, F. R-1202, Op. 1, Spr. 79. (In Ukrainian).

Protokoly No. 81, 82 zasidan' TsK natsional'nykh menshostey ta materialy do nykh, TsDAVO Ukrayiny, F. 413, Op. 1, Spr. 158. (In Ukrainian).

Protokoly No. 1-23 zasidan' TsK natsional'nykh menshostey, TsDAVO Ukrayiny, F. 413, Op. 1, Spr. 242.

Protokoly zasidan' TsK natsional'nykh menshostey ta materialy do nykh, TsDAVO Ukrayiny, F. 413, Op. 1, Spr. 168. (In Ukrainian).

Rubl'ov O. and Yakubova L. (2014), Orhany etnopolitychnoho rehulyuvannya $v$ konteksti polityky korenizatsiyi: ukrayins 'kyy dosvid, Inst. Ist. Ukrayiny NANU, Kyiv. (In Ukrainian).

Spiridonov D. (1930), "Istorychnyy interes do hovirok mariyupol's'kykh hrekiv", Shidnij svit, No. 12, pp. 171-81. (In Ukrainian).

Tyuryakulov N. (1924), "K voprosu o latinskom alfavite sredi tyurkov SSSR", Zhizn' natsional'nostey, No. 1, pp. 38-40. (In Russian).

Statystychnyy byuleten' Mariupol'shchyny (shchomisyachne vydannya Mariupol's 'koho statystychnoho byura) (1926-1927), No. 9-11 
Turkic-Speaking Population of the Donbas in the Soviet Indigenization...

(cherven'-serpen'), Tsentral'ne statystychne upravlinnya Ukrayiny. (In Ukrainian).

Yakubova L. (2010), "Hrets'ke selo v hornyli 'bil'shovyts'koyi perekovky' (20-ti rr. XX st.)", Problemy istoriyi Ukrayiny: fakty, sudzhennya, poshuky: Mizhvid. zb. nauk. pr., Vol. 19 (1), pp. 173-217. (In Ukrainian).

Yakubova L. (2014), Etnonatsional'na istoriya Donbasu: tendentsiyi, superechnosti, perspektyvy $v$ svitli suchasnoho etapu ukrayins'koho natsiotvorennya, Inst. Ist. Ukrayiny NANU, Kyiv. (In Ukrainian).

Yali S. (1931), Hreky v USRR, Vseukrayins'ka filiya Tsentrvydavu narodiv SRSR pry prezydiyi VUTsVK, Kharkiv. (In Ukrainian).

\section{I. Мартинчук, О. В. Отземко \\ ТЮРКОМОВНЕ НАСЕЛЕННЯ ДОНБАСУ \\ В РАДЯНСЬКІЙ ПОЛІТИЦІ КОРЕНІЗАЦЇ̈}

У статті розглядаються напрямки радянської політики коренізації 1920-х - початку 1930-х років стосовно тюркомовного населення Донбасу, під яким маються на увазі татари та уруми (греки-тюркофони). Донбас сформувався як один із поліетнічних регіонів України і в рамках дослідження становить територію сучасної Донецької та Луганської областей. Вивчення зазначеної проблеми стало можливим унаслідок залучення широкого кола джерел, передусім, документів комуністичної партії, оскільки остання повністю контролювала втілення політики коренізації; діловодної документації органів влади; статистичних і довідкових матеріалів. Заходи коренізації були проаналізовані з огляду на особливості проживання в регіоні татар та чисельної тюркомовної групи греків Приазов’я (урумів). Основна увага зосереджена на питаннях адміністративно-територіального районування та безпосередньо пов'язаної з цим спробі вирішення мовної проблеми тюркомовного населення Донбасу. Розглянуто ідеологічні та організаційні засади коренізації. Показано, що у 19261931 рр. було створено три національні грецькі райони, один 3 яких Мангушський з урумським населенням, i 14 урумських сільських рад. Істотні недоліки в їхній діяльності зумовили низьку виборчу активність місцевого населення. У статті робиться висновок, що важливим напрямком роботи серед тюркомовного 
населення Донбасу було мовне питання, яке набуло гостроти у зв'язку з необхідністю створення адміністративного апарату за національної ознакою, запровадження діловодства національними мовами. У дискусії з цього приводу брав участь А. Кримський. Вирішення мовного питання мало і політичне значення: створення умов для поширення радянського способу життя, антирелігійної пропаганди, сприяння "інтернаціональному вихованню” тюркомовного населення. Загалом коренізація не розв'язала проблем цих етнічних меншин, водночас сприяла залученню їх у прискорені процеси радянської модернізації Донбасу, які 3 початку 1930-х років набули більш жорсткого і репресивного характеру.

Ключові слова: тюркомовне населення, татари, уруми, коренізація, адміністративно-територіальне районування, Донбас

Стаття надійшла до редакиії 26.08.2021 